\title{
Race and Right-Wing Authoritarianism: How Scoring High in Authoritarianism does not Necessarily Lead to Support for Right-Wing Candidates
}

\author{
Dr. Aaron Dusso \\ Assistant Professor \\ Indiana University-Purdue University Indianapolis \\ Department of Political Science \\ 425 University Blvd. CA 503g \\ Indianapolis, IN 46202 \\ Phone: 317-278-0704 \\ Fax: 317-278-3280 \\ adusso@iupui.edu
}

Direct all correspondence to Dr. Aaron Dusso.

Dr. Aaron Dusso shall share all data and coding for replication purposes.

Thanks: This research was made possible by a grant from Indiana University's New Frontiers in the Arts and Humanities program.

\begin{abstract}
Objectives: Authoritarianism has a long history suggesting that it is primarily a phenomenon of the right. However, I argue that this has led to scholars overlooking the potential that in some contexts, authoritarianism can lead to support for left-wing candidates. African-American voters in the U.S. provide such a context. A key component of right-wing authoritarianism is that individuals will support whom they believe to be their rightful leader. In the U.S., who one believes to be their group's rightful leader is contingent on the race of the voter and the party of the candidate. I hypothesize that as African-American voters' level of authoritarianism increases, they will be more likely to support the left-wing Democratic candidate.

Methods: I test this hypothesis with a national sample of voters after the 2012 U.S. presidential election. I estimate multiple logit models predicting the probability of voting for Obama. The key independent variables being respondents' right-wing authoritarian score, their race, and the interaction of these two variables.

Results: The results present strong support for my hypothesis that an increase in right-wing authoritarianism increases the probability of African-American votes choosing Obama.

Conclusion: The results show that the effect of authoritarianism on vote choice is contingent on race/ethnicity. Too often scholars have overlooked the potential that whom individuals deem to be their established authority is contingent on the political context. These results challenge scholars to provide a more nuanced approach to how authoritarianism influences behavior.
\end{abstract}

This is the author's manuscript of the article published in final edited form as: 
The concept of authoritarianism has generated a considerable amount of work over the last sixty years. Altemeyer (1981) is typically credited with developing the first modern psychological measurement techniques applied to the concept. One of the keys to Altemeyer's definition of what he termed right-wing authoritarianism (RWA) is that individuals are “relatively submissive to those they consider the established authorities" (2004, p. 426). This is an important yet often overlooked component of the authoritarian follower. As one would expect, given the name, work has shown RWA to lead to support for right-wing political parties and candidates (e.g., De Koster and Van der Wall 2007; De Witte and Billiet 1999; Leone et al. 2014; Van Hiel and Mervielde 2002). However, this largely ignores the U.S. racial and political context. Decades of research, along with seminal works in the arts and humanities such as Ralph Ellison's Invisible Man, have documented the differing experiences, treatment, socialization, and group identification of African-Americans (e.g., Boykin and Toms 1985; Cooper and Smalls 2010; Kaiser and Wilkins 2010; Knuycky, Kleider, and Cavrak 2014; Monroe 2013; Tajfel and Turner 1986; Tatum 1997). I argue that it is highly unlikely that African-American voters view a wealthy, white, conservative, Republican (i.e., Mitt Romney) as their established authority. Thus, I propose the relatively novel hypothesis that as African-Americans' RWA score increases, they will be more likely to vote for the Democratic candidate.

The work presented here builds on earlier research attempting to demonstrate the effect of authoritarianism on the choices individuals make in the voting booth, while controlling for the effect of the economy and partisanship, which is rarely ever done. I test the predictive value of the RWA scale with a national survey of voters after the 2012 U.S. presidential election. I find, first, that RWA is a significant predictor of voting during the 2012 elections. Second, contrary to 
the received wisdom regarding RWA, African-American voters are more likely to support the Democratic candidate in the 2012 U.S. presidential election as their RWA score increases.

\section{Right-Wing Authoritarianism}

Research on the authoritarian personality stretches back to the post WWII era. It was largely motivated by a desire to understand how the Nazi Party was able to not only rise to prominence after the First World War, but come to dominate Germany with so many seemingly devoted followers (Adorno et al 1950). The ensuing decades of research have found that authoritarians tend to find themselves on the right side of the ideological spectrum (Hetherington and Weiler 2009; Meloen 1993; Stone 1980; Stone, Lederer, and Christie 1993; Todosijević and Enyedi 2008). Altemeyer's (1981, 1988, 1996, 1998) works pushed the concept forward by eliminating many of the methodological problems associated with the original measures of the authoritarian personality. He also makes no pretense about where this measure tends to find its strongest adherents and simply calls it right-wing authoritarianism.

Altemeyer altered the concept by moving away from the Freudian foundations of its first iterations and centered it as primarily a social psychological theory. In doing so, he generated a scale that measures RWA. This concept consists of three key components. First, individuals are highly submissive to those they perceive to be legitimate authorities. Second, individuals evince a high degree of out-group aggression when it is sanctioned by the legitimate authorities. Third, individuals express high levels of support for what they believe to be conventional or traditional values or behaviors.

The concept of RWA has spawned a considerable amount of work, the bulk of which has been focused on its effects on attitudes and beliefs rather than demonstrating its effect on behavior. Some of the most prominent of these works are those demonstrating that scoring high 
on the RWA scale leads to an increased likelihood of prejudice (Altemeyer 1998; McFarland, Ageyev, and Djintcharadze 1996; Pratto, Sidanius, and Levin 2006; Raden 1999). However, the findings are certainly not limited to prejudice. Individuals scoring high on the RWA scale are also more likely to favor the use of military force (Doty et al. 1997; Hetherington and Suhay 2011), skew toward fundamentalist religious beliefs (Hunsberger 1995), and have less support for democratic values (Canetti-Nisim 2004) and universal human rights (McFarland and Mathews 2005). They are also lower in political knowledge and generally less interested in learning (Peterson, Duncan, and Pang 2002), although political experts appear to be better able to make the ideological connection between authoritarianism and conservatism (Federico, Fisher, and Deason 2011). In a particularly interesting study, Lavine et al. (1999) find that one’s level of authoritarianism moderates the influence of political messages. Individuals scoring high in authoritarianism respond more readily to threat messages, while those low in authoritarianism are more responsive to reward messages (see also Lavine, Lodge, and Freitas 2005; Lavine et al. 2002; Mirisola et al. 2014).

There have also been demonstrations of RWA's effect on behavior. Scoring higher on the RWA scale can lead to an increased likelihood of returning guilty verdicts (Narby, Cutler, and Moran 1993) and to have committed sexual assault (Walker, Rowe, and Quinsey 1993). In their recent study of the effects of authoritarianism, Hetherington and Weiler (2009) find that scoring high in authoritarianism affects the likelihood of turning out to vote. In the 2000 and 2004 elections, non-African-American Democrats scoring high in authoritarianism were less likely to turnout to vote, while high scoring Republicans were more likely to turnout. They also find the expected difference between the average authoritarianism scores for the Republican and 
Democratic candidates, with the largest difference occurring in 2004 when Republican voters scored 14.5 percent higher than Kerry voters.

When it comes to voting in the 2012 presidential election, the obvious expectation is that the higher one scores on the RWA scale, the less likely the individual is to vote for the Democratic African-American candidate, i.e., Obama. However, within the RWA concept of the authoritarian follower is the subjective condition that the individual follows whom they perceive to be the rightful leader. In its broadest conception, this means simply following the established power structure and suggests that the higher one scores on the RWA scale, the more likely one is to vote for the incumbent president. However, this would largely ignore the racial components of an election with an African-American president seeking reelection. I hypothesize that the effect of the RWA disposition is contingent on race/ethnicity. For white voters, as their score on the RWA scale goes up, they will be more likely to vote for Romney, while for African-American voters, as their RWA score goes up, the more likely they will be to vote for Obama.

The supposition that African-Americans will be more likely to vote for Obama as their RWA score increases is a novel one. The idea here begins with the key component of RWA, as defined by Altemeyer (2004), that individuals are "relatively submissive to those they consider the established authorities” (p. 426). To date, research on the effects of authoritarianism in the U.S. has largely ignored the potential that the race/ethnicity of the candidates will cause different responses from voters, independent of the ideological content of the candidates' messages. Thus, one might myopically predict that African-Americans scoring high on RWA will be more likely to support Romney. However, it is hard to justify why an African-American voter in 2012 would look to a wealthy, white, conservative, Republican as their established authority. If submission to whom one perceives as their established authority has any meaning, it surely must vary 
depending on the combination of who the individual voter is and the options he or she has in the voting booth. In the case of African-American voters in 2012, they have the option to support either a white, conservative Republican or an African-American, liberal, Democrat. Research on African-American group identity and voting behavior can help determine which candidate African-Americans will see as their established authority.

Extant research indicates that African-Americans have a long history of conservative social values (Bolce 1992; Bolce and Gray 1979; Combs and Welch 1982; Kidd et al. 2007; Seltzer and Smith 1985; Watson 1998). Thus, the portions of the RWA scale tapping traditional or conservative values will capture these beliefs. However, whom African-Americans scoring higher on the RWA will be more likely to support is different than whom high scoring whites will support for two reasons. First, African-American voting behavior indicates a strong preference for Democratic candidates. Second, ceteris paribus, African-Americans respond to African-American candidates differently than they do to white candidates. This first claim is not controversial, however the second requires further elucidation.

The importance of group identification has been the focus of study for decades (e.g., Miller et al. 1981; Tajfel 1981). Conover (1984) makes the important connection between group identification and politics by demonstrating how group identification leads to significant differences in how individuals evaluate the political world. The most basic empirical realization of this has been demonstrated numerous times; i.e., as the population of African-Americans increases, the probability of an African-American being elected increases (Branton 2009; Canon 1999; Guinier 1994; Lublin 1997). While the simple dyadic relationship between AfricanAmerican constituencies and African-American office holders has produced mixed results regarding its effect on African-American turnout (Gay 2001; Tate 2003; Griffin and Newman 
2008; Philpot and Walton 2007), those taking a broader look at the effects of the political environment as a whole have found an increase in participation where there is significant African-American representation. For example, Bobo and Gilliam (1990) demonstrate that African-American participation increases in areas with African-American mayors (see also Smith 1978). Rocha et al. (2010) demonstrate that African-American turnout increases in states with greater African-American representation in the state legislature. In addition, there are a large number of works that show how political trust among African-Americans increases with descriptive representation (Abney and Hutcheson 1981; Howell and Fagan 1988; Tate 2003).

In perhaps the most direct demonstration of African-American group identity and candidate support, Tate (2003) utilizes the 1996 National Black Election Study survey and shows that African-Americans believe that African-Americans represent their interests in Congress better than whites. Sullivan and Arbuthnot (2009) echo these findings. However, they move beyond aggregate survey results and produce an experimental design to test this idea and find that African-Americans are more likely to support African-American than white candidates. Moving beyond the voting booth, Scherer and Curry (2010) also use an experimental design and find that greater descriptive representation in federal courts increases perceptions of the system's legitimacy among African-Americans. All told, it appears reasonable to conclude from the research that, all else equal, African-Americans prefer African-American political representation. This is a general finding. Here I argue that authoritarianism can intensify this desire for AfricanAmerican representation.

\section{Testable RWA Hypotheses}

To summarize, I will test the following two RWA hypotheses:

H1: As white voters' RWA scores increase, the probability that they will vote for Obama will decrease. 
H2: As African-American voters’ RWA scores increase, the probability that they will vote for Obama will increase.

\section{Data Methods}

In order to explore the role of right-wing authoritarianism in driving vote choice during the 2012 presidential election, a national survey of voters was implemented from November $15^{\text {th }}$ through the $19^{\text {th }}$. The survey was hosted and designed in Qualtrics’ online survey research suite. Sampling was done through Survey Sampling International’s (SSI) online sampling approach. ${ }^{1}$ SSI was founded in 1977 and maintains 34 ongoing panels to form the core of its online sample. Knowing the potential problem with selection bias inherent in an opt-in online survey, SSI improves the quality of its sample by further recruiting participants from online communities, social networks, and websites of all types. In doing so, SSI can potentially reach anyone online through their network of relationships with these online communities, websites, and social media groups. SSI insures the representativeness of the sample and minimizes the risk of bias through a three-stage randomization process. First, participants are randomly selected from SSI's panels to be invited to take a survey, and these participants are combined with others entering SSI's sampling platform after responding to online messaging (through invitations of all types, including e-mail, SMS, text, telephone, banner ads, and messaging on websites and online communities). Second, a set of profiling questions (never affirmation questions) is randomly selected for them to answer. Third, upon completion, participants are matched with a survey they are likely to be able to take, using a further element of randomization. ${ }^{2}$

****Table 1 about here $* * * *$

\footnotetext{
${ }^{1} \mathrm{SSI}$ has been used by scholars in many other works in the field (e.g., Esterling, Neblo, and Lazer 2011; Fahimi, Kulp, and Brick 2009; Malhotra and Margalit 2010; Popp and Rudolph 2011).

${ }^{2}$ Further information on SSI's sampling process was provided to the author and is available upon request.
} 
For this work, a sample of voters in the 2012 presidential election was selected. Wherever possible, the survey questions ${ }^{3}$ were direct copies of the wording used in American National Election Studies (ANES) surveys; e.g., all demographic questions (race/ethnicity, gender, age, income and educational attainment) and questions designed to measure party identification, ideology, and thoughts about the economy and political knowledge. See Table 1 for coding rules for each variable. The RWA scale was adopted from Altemeyer (2004), which was chosen for two reasons. First, it has a long history and has been tested across numerous cultural and political contexts (Ahrens and Innes 1994; Rubinstein 2003; Duckitt and Fisher 2003; McFarland, Ageyev, and Djintcharadze 1996; Duriez and Van Hiel 2002; Ekehammar et al. 2004). Second, one of primary criticisms of the RWA scale rests on the potential tautological reasoning that can occur when using it. That is, scholars have used the RWA to explain ideology in many contexts. The problem with this is that many of the very same elements go into measuring both RWA and ideology. Thus, these analyses are problematic. However, here I am attempting to explain vote choice, not ideology. In addition, I include a control variable for ideology in the models presented. Thus, there is little reason to suspect a circularity problem here.

****Table 2 about here ${ }^{* * * *}$

The RWA scale contains 30 questions. Each question is essentially a statement and the respondent is given a nine point scale to rate their agreement or disagreement with the particular statement. The scale is balanced so that half the questions would require the hypothetical high RWA person to answer "very strongly agree" and then answer "very strongly disagree" to the other half. Each scale is then coded so that the least socially dominant or authoritarian answer is

\footnotetext{
${ }^{3} \mathrm{~A}$ copy of the full survey is available from the author upon request.
} 
coded 1 , while the most is coded 9. Thus, the RWA scale ranges from a low of 30 to a high of $270 .{ }^{4}$ Table 2 contains a list of each of the 30 RWA questions. The scale yields an average interitem correlation of 0.41 and a Cronbach alpha of 0.95 .

****Table 3 about here ${ }^{* * * *}$

Table 3 shows the demographic breakdown of the sample of 1751 voters as compared to the Associated Press' (AP) exit polling conducted in 350 places and comprising of 26,000 Election Day voters. The survey I conducted through SSI is not a representative sample of the country. A quota system was used to match the sample to the distribution of the voting population along gender and race/ethnicity. Since the research conducted here is not attempting to estimate a population level statistic like the percent of people who voted for Romney, a representative sample is not necessary. I am attempting to document an individual level effect, i.e., the effect of authoritarianism on voting. The effects of psychological dispositions are documented using non-probability samples with regularity. Indeed, Altemeyer's original work on RWA is not based on a representative sample of the Canadian population, but on a sample of convenience. In order for the survey I use here to be problematic, one would need to show that I am not controlling for a variable that is driving participation in the survey and both one's level authoritarianism and one's vote choice (Wooldridge 2013). I am unware of any such variable.

As can be seen in Table 3, this sample appears to be a bit less wealthy and a little older, on average, than AP's exit polling sample. I control for both age and income in the multiple regressions presented below, thus this fact is not driving the result. All told, the survey's

\footnotetext{
${ }^{4}$ Coding the scores from 1 to 9 was done in order to maintain consistency with past work. In the regressions I subtract 30 from the scale so that the scales begin at 0 . This makes it easier to interpret the results of the interactions.
} 
distribution appears to be broadly similar to that of the AP's. The following regressions will rely on a subset ( $\mathrm{N}=761$ ) of the overall sample because respondents were randomly chosen to receive the RWA questions. As can be seen, there are some differences between the RWA subset and the overall sample, but they are broadly similar.

\section{Results}

****Table 4 about here $* * * *$

Table 4 presents results after estimating two logit models predicting voting for Obama in 2012. The two models are the same except for the inclusion of the interaction between the variables African-American and RWA in Model 2. The interaction between these two variables is the key to testing hypotheses $\mathrm{H} 1$ and $\mathrm{H} 2$. Looking at Model 1, the RWA scale fails to reach significance. The other included variables perform as one would expect. Each of the race and ethnicity variables is highly significant. In this case, "white" is the dropped category and thus each of the coefficients on the remaining categories (African-American, Hispanic/Latino, and Other Race) is understood as compared to the dropped category. Therefore, the significant positive African-American result indicates that African-Americans are more likely to vote for Obama than whites.

Model 2 in Table 4 provides the test of each of the hypotheses. As can be seen, once the interaction is included, neither RWA nor African-American reach significance, but the interaction does. With the interaction included in the model, the meaning of each of the other variables changes. In this case, the meaning of the coefficient on the RWA variable is the effect of RWA when African-American equals 0. Thus, this is the test of the hypothesis H1. Since it falls short of conventional levels of significance, it fails to provide support for H1. Looking at African-American, the meaning of this coefficient is the effect of African-American when RWA 
equals 0 . This would be the least authoritarian individuals and it is not too surprising to see that it also falls short of significance. The total effect of RWA for African-American voters is found with the combination of both the interaction variable and the African-American variable. First, the significant interaction indicates that the effect of RWA is conditional on one's race. Second, a joint hypothesis test of the interaction and the African-American variables is significant indicating that the probability of African-Americans' voting for Obama is conditional on their level of RWA.

****Figure 1 about here****

Interaction terms are notoriously difficult to interpret from simple output tables. Therefore, Figure 1 presents the marginal effect of RWA on white and African-American votes as one's RWA score increases from $28\left(10^{\text {th }}\right.$ percentile) to $164\left(90^{\text {th }}\right.$ percentile), holding all other variables at their mean. The circle line represents African-American voters. At a score of 28, they have a .52 probability of voting for Obama. This jumps to .84 with an RWA score of 164 . Of course, this .32 increase in the probability of voting for Obama is not the largest effect found in the model. As a comparison, moving from identifying as a Republican (score of 2 on the partisanship scale) to Democrat (score of -2) is associated with an increases of .58 in the probability of voting for Obama. However, in the case of sociotropic beliefs about the economy, RWA's effect is quite a bit larger. Moving from thinking the economy is doing worse (score of 1 on the sociotropic economy measure) to thinking it is doing better (score of 1) is associated with only a .12 increase in the probability of voting for Obama. Thus, the effect of RWA falls somewhere between two of the most commonly referenced voting variables, i.e., partisanship and the state of the economy. 
Finally, the line with the " $x$ " marking in Figure 1 represents the effect of RWA for white voters. As was evident from Table 4, the change for whites as RWA increases is not significant, although it does have the predicted slope. Figure 1 also makes it easy to see that the differing effects for whites and African-Americans begin at about a RWA score of 84, which is about the $34^{\text {th }}$ percentile score. Thus, there is not a statistically significant difference between whites' and African-Americans' probability of voting for Obama when one is low in right-wing authoritarianism. All told, between Table 4 and Figure 1, there is strong evidence supporting hypothesis $\mathrm{H} 2$ in this data.

Closer Look at RWA's Multiple Dimensions and African-American and White Respondents Duckitt and Bizumic (2013; see also Duckitt et al. 2010) have argued that the RWA scale consists of three distinct facets. They define them as follows: "Authoritarianism (defined as attitudes favoring strict, tough, harsh, punitive social control versus leniency and indulgent permissiveness to the violation of social rules, norms and laws), Conservatism (defined as attitudes favoring uncritical, respectful, obedient support for existing societal authorities and institutions versus critical, questioning, rebellious, oppositional attitudes to them), and Traditionalism (defined as attitudes favoring traditional, old fashioned, religious social norms, values, and morality versus modern, liberal, secular, bohemian, 'alternative,' norms, values, and morality)" (843). Thus, in the Duckitt and Bizumic conception Conservativism corresponds to authoritarian submission, Authoritarianism corresponds to authoritarian aggression, and Traditionalism simply represents traditionalism.

Given the argument presented here that African-Americans find the Democratic candidate to be the proper authority, I would expect this to be primarily driven by the Conservative facet of the RWA scale. Unfortunately, Altemeyer's RWA scale does not map 
perfectly onto Duckitt and Bizumic’s newer tripartite scale. Given this limitation, I have coded the RWA questions (see Table 2) in order to approximate the three components of RWA. This produces extremely rough measures because the scales are not balanced and not all of Altemeyer's questions could be clearly placed in one or the other category because they contained multiple of the facets in a single question. For example, the RWA question, "The only way our country can get through the crisis ahead is to get back to our traditional values, put some tough leaders in power, and silence the troublemakers spreading bad ideas,” contains all threetraditionalism, submission, and aggression.

****Figure 2 about here ${ }^{* * * *}$

The results of this exercise can be found in Figure $2 .{ }^{5}$ Part A of Figure 2 depicts change in the probability of voting for Obama as one’s Authoritarianism (i.e., authoritarian aggression) moves from 6 ( $10^{\text {th }}$ percentile score) to $41\left(90^{\text {th }}\right.$ percentile score) for African-American (solid line) and white (dashed line) voters. In both instances the 95 percent confidence intervals indicate that there is not a statistically significance relationship between this aspect of RWA and voting for Obama. In other words, functionally, both lines are flat. Part B measures the aspect of RWA that I have pointed to as being particularly important. As was the case with the results of the overall model in Figure 1, as African-Americans' scores in the Conservatism (i.e., authoritarian submission) dimension of RWA increases, they are more likely to vote for Obama. The result for white voters fall just short of standard levels of significance. Finally, Part C depicts the results for RWA's Traditionalism dimension. As was the case in Part B, as AfricanAmericans' scores increase, the more likely they are to vote for Obama. However, unlike in Part

\footnotetext{
${ }^{5}$ Full results for each model available upon request.
} 
B, the effect is statistically significant for white voters too, but in the opposite direct. That is, as white voters' scores in Traditionalism increase, they are less likely to vote for Obama.

While keeping in mind the imprecision of these measures, the results are consistent with what I would expect to see if African-Americans do indeed find Democratic leaders to be the legitimate established authority. In addition, the Traditionalism aspect of RWA also shows a strong divide between how white and African-Americans respond to changes in their scores, whereas the authoritarian aggression dimension fails to reach significance in either case. These results clearly indicate that there is a more complex relationship occurring between RWA and political behavior in the U.S. than has heretofore been explored. The racial context alters the effect of authoritarianism on political participation. Ultimately, these results demonstrate the need for further scholarly investigation of this effect with more precise measures of each of the three dimensions of RWA.

\section{Discussion}

Authoritarianism has been the subject of study for decades and has been linked to a wide variety of attitudes and behaviors. As scholars of voting behavior move forward and continue to refine our understanding of the choices people make in the voting booth, the results presented here indicate the need to incorporate psychological dispositions like the RWA scale. Importantly, the regressions control for the effects of both partisanship and the economy on presidential vote choice. When attempting to explain vote choice, failing to control for these two fundamental variables renders any results highly suspect. For example, failing to control for voters' beliefs about the state of the economy in Model 2 of Table 4 would result in underestimating the effect of RWA on African-Americans' votes by about 25 percent. ${ }^{6}$

\footnotetext{
${ }^{6}$ This was determined by re-estimating Model 2 in Table 4 without the two economy variables.
} 
The results also show that the effect of authoritarianism on vote choice is contingent on race/ethnicity. Too often scholars have overlooked the potential that whom individuals deem to be their established authority is contingent on the political context. High RWA scoring AfricanAmericans are not switching to the right-wing Republican candidate, but are more likely to support the left-wing Democratic candidate. This is a new finding and challenges scholars to provide a more nuanced approach to how authoritarianism influences behavior. Identifying who an individual believes to be the rightful leader is critical to understanding whom that individual is likely to follow. Heretofore, work has focused too much on matching abstract political ideologies and issue positions to authoritarian beliefs and disregarded the need for authoritarian followers to clearly identify with their chosen leader.

Of course, the results presented here are limited to the 2012 election. One difficulty with this particular data is that it cannot parse how much of what is driving African-American voters is attributable to either their traditional support for the Democratic Party or the fact that the Democratic candidate was also an African-American. I suspect that this combination exacerbates the effect of RWA because it makes it easier for individuals to distinguish between the two candidates, thus, obviating the difference between low and highly knowledgeable voters. For example, the work of Federico, Fisher, and Deason (2011) has demonstrated that it is easier for those high in political knowledge to make the connection between attitude orientation and political candidate than for those low in political knowledge. Therefore it seems reasonable to suspect that any variable that can lessen the cognitive burden for those lower in political knowledge should make the effect of RWA more acute.

Finally, another line of work that would benefit from the inclusion of the RWA scale is that which is focused on the concept of incorrect voting (e.g., Dusso 2015; Lau and Redlawsk 
1997, 2006; Lau, Andersen, Redlawsk 2008). This line of work suggests that voters often lack complete information about the policy positions of the candidates and as a result pick the wrong one (somewhere between 20-30 percent of voters by their estimates). Does right-wing authoritarianism lead voters to support candidates they otherwise would not? Or perhaps those falling on either extreme of the RWA spectrum (and thus having more consistent attitudes) are able to better connect their attitudes to the correct candidate. The notion of incorrect voting deserves more attention and a psychological concept like RWA will help shed light on how and why individuals choose the wrong candidate. 


\section{References}

Abney, F. Glenn, and John D. Hutcheson, Jr. 1981. "Race, Representation, and Trust: Changes in Attitudes After the Election of a Black Mayor.” Public Opinion Quarterly 45: 91-101.

Adorno, Theodor W., Else Frenkel-Brunswik, Daniel Levinson, and R. Nevitt Sanford. 1950. The Authoritarian Personality. New York: Harper.

Ahrens, C. R., and J. M. Innes. 1994. “Attribution of Right-Wing Authoritarianism as a Function of Self-Perceived Political Opinion.” Journal of Social Psychology 134: 383-385.

Altemeyer, Bob. 1981. Right-Wing Authoritarianism. Winnipeg, Manitoba, Canada: University of Manitoba Press.

Altemeyer, Bob. 1988. Enemies of Freedom. San Francisco: Jossey-B ass.

Altemeyer, Bob. 1996. The Authoritarian Specter. Cambridge, MA: Harvard University Press. Altemeyer, Bob. 1998. “The Other 'Authoritarian Personality.”” In Advances in Experimental Social Psychology, ed. M.P. Zanna, Vol. 20, pp. 47-92. San Diego, CA: Academic. Altemeyer, Bob. 2004. “The Other 'Authoritarian Personality.'” In Political Psychology eds. John T. Jost and Jim Sidanius. New York: Psychology Press.

Bobo, Lawrence, and Franklin D. Gilliam, Jr. 1990. "Race, Sociopolitical Participation, and Black Empowerment.” American Political Science Review 84: 377-393.

Bolce, Louis, and Susan Gray. 1979. “Blacks, Whites, and Race Politics.” Public Interest 53: 6175.

Bolce, Louis. 1992. “Blacks and the Republican Party: The 20 Percent Solution.” Political Science Quarterly 107: 63-79.

Boykin, A. W. and F. Toms. 1985. “Black Child Socialization: A Conceptual Framework.” In African American Youth: Their Social and Economic Status in the United States. R.L. Taylor (Ed.). Connecticut: Praeger. Pp. 93-142.

Branton, Regina P. 2009. “The Importance of Race and Ethnicity in Congressional Primary Elections.” Political Research Quarterly 62: 459-473.

Canetti-Nisim, Daphna. 2004. “The Effect of Religiosity on Endorsement of Democratic Values: The Mediating Influence of Authoritarianism.” Political Behavior 26: 377-398. 
Canon, David T. 1999. Race, Redistricting, and Representation: The Unintended Consequences of Black Majority Districts. Chicago: University of Chicago Press.

Combs, Michael W., and Susan Welch. 1982. "Blacks, Whites, and Attitudes Toward Abortion.” Public Opinion Quarterly 46: 510-20.

Conover, Pamela Johnston. 1984. "The Influence of Group Identifications on Political Perception and Evaluation.” The Journal of Politics 46: 760-785.

Cooper, Shauna M., and Ciara Smalls. 2010. “Culturally Distinctive and Academic Socialization: Direct and Interactive Relationships with African American Adolescents’ Academic Adjustment.” Journal of Youth and Adolescence 39: 199-212.

De Koster, Willem, and Jeroen van der Waal. 2007. "Cultural Value Orientations and Christian Religiosity: On Moral Traditionalism, Authoritarianism, and Their Implications for Voting Behavior.” International Political Science Review 28: 451-467.

De Witte, H., and J. Billiet. 1999. "Economic and Cultural Conservatism in Flanders: In Search of Concepts, Determinants and Impact on Voting Behaviour.” In H. De Witte and P. Scheepers (Eds.) Ideology in the Low Countries. Trends, Models and Lacunae, pp. 91120. Assen: Van Gocum.

Doty, R.M., D.G. Winter, B.E. Peterson, and M. Kemmelmeier. 1997. "Authoritarianism and American Students’ Attitudes about the Gulf War, 1990-1996.” Personality and Social Psychology Bulletin 23: 41-49.

Duckitt, John, and Boris Bizumic. 2013. "Multidimensionality of Right-wing Authoritarian Attitudes: Authoritarianism-Conservatism-Traditionalism.” Political Psychology 34: 841862.

Duckitt, John, Boris Bizumic, Stephen W. Krauss, and Edna Heled. 2010. “A Tripartite Approach to Right-Wing Authoritarianism: The Authoritarianism-ConservativismTraditionalism Model.” Political Psychology 31: 685-715.

Duckitt, John, and Kristin Fisher. 2003. "The Impact of Social Threat on Worldview and Ideological Attitudes.” Political Psychology 24: 199-222.

Duriez, Bart, and Alain Van Hiel. 2002. "The March of Modern Fascism. A Comparison of Social Dominance Orientation and Authoritarianism.” Personality and Individual Differences 32: 1199-1213. 
Dusso, Aaron. 2015. “Incorrect Voting in the 2012 U.S. Presidential Election: How Partisan and Economic Cues Fail to Help Low-Information Voters.” Electoral Studies 37: 50-62.

Ekehammar, Bo, Nazar Akrami, Magnus Gylje, and Ingrid Zakrisson. 2004. "What Matters Most to Prejudice: Big Five Personality, Social Dominance Orientation, or Right-Wing Authoritarianism? European Journal of Personality 18: 463-482.

Esterling, Kevin M., Michael A. Neblo, and David M. J. Lazer. 2011. “Means, Motive, and Opportunity in Becoming Informed about Politics: A Deliberative Field Experiment with Members of Congress and Their Constituents.” Public Opinion Quarterly75: 483-503.

Fahimi, Mansour, Dale Kulp, and J. Michael Brick. 2009. “A Reassessment of List-Assisted RDD Methodology.” Public Opinion Quarterly 73: 751-760.

Federico, Christopher, Emily L. Fisher. Grace Deason. 2011. "Expertise and the Ideological Consequences of the Authoritarian Predisposition.” Public Opinion Quarterly 75: 686708.

Gay, Claudine. 2001. “The Effect of Black Congressional Representation on Political Participation.” American Political Science Review 95: 589-602.

Griffin, John D., and Brian Newman. 2008. Minority Report: Evaluating Political Equality in America. Chicago: University of Chicago Press.

Guinier, Lani. 1994. The Tyranny of the Majority: Fundamental Fairness in Representative Democracy. New York: Free Press.

Hetherington, Marc J., and Elizabeth Suhay. 2011. “Authoritarianism, Threat, and Americans’ Support for the War on Terror.” American Journal of Political Science 55: 546-460.

Hetherington, Marc, and Jonathan D. Weiler. 2009. Authoritarianism and Polarization in American Politics. Cambridge, UK: Cambridge University Press.

Howell, Susan, and Deborah Fagan.1988. “Race and Trust in Government.” Public Opinion Quarterly 52: 343-350.

Hunsberger, B. 1995. "Religion and Prejudice: The Role of Religious Fundamentalism, Quest, and Right-Wing Authoritarianism.” Journal of Social Issues 51: 113-129.

Kaiser, Cheryl R., and Clara L. Wilkins. 2010. “Group Identification and Prejudice: Theoretical and Empirical Advances and Implications.” Journal of Social Issues 66: 461-476. 
Kidd, Quentin, Herman Diggs, Mehreen Farooq, and Megan Murray. 2007. "Black Voters, Black Candidates, and Social Issues: Does Party Identification Matter?” Social Science Quarterly 88: 165-176.

Knuycky, Leslie R., Heather M. Kleider, and Sarah E. Cavrak. 2014. “Line-up Misidentifications: When Being 'Prototypically Black' is Perceived as Criminal.” Applied Cognitive Psychology 28: 39-46.

Lau, Richard R. and David P. Redlawsk. 1997. "Voting Correctly.” The American Political Science Review 91: 585-598.

Lau, Richard R. and David P. Redlawsk. 2006. How Voters Decide: Information Processing during Election Campaigns. New York: Cambridge University Press.

Lau, Richard R., David J. Andersen, and David P. Redlawsk. 2008. “An Exploration of Correct Voting in Recent U.S. Presidential Elections.” American Journal of Political Science 52: 395-411.

Lavine, Howard, Diana Burgess, Mark Snyder, John Transue, John L. Sullivan, Beth Haney and Stephen H. Wagner. 1999. “Threat, Authoritarianism, and Voting: An Investigation of Personality and Persuasion.” Personality and Social Psychology Bulletin 24: 337-347.

Lavine, Howard, Milton Lodge, and Kate Freitas. 2005. “Threat, Authoritarianism, and Selective Exposure to Information.” Political Psychology 26: 219-244.

Lavine, Howard, Milton Lodge, James Polichak, and Charles Taber. 2002. "Explicating the Black Box Through Experimentation: Studies of Authoritarianism and Threat.” Political Analysis 10: 343-361.

Leone, Luigi, Marta Desimoni, and Antonio Chirumbolo. 2014. "Interest and Expertise Moderate the Relationship between Right-Wing Attitudes, Ideological Self-Placement and Voting.” European Journal of Personality 28: 2-13.

Lublin, David. 1997. The Paradox of Representation: Racial Gerrymandering and Minority Interests in Congress. Princeton, NJ: Princeton University Press.

Malhotra, Neil, and Yotam Margalit. 2010. "Short-Term Communication Effects or Longstanding Dispositions? The Public's Response to the Financial Crisis of 2008.” The Journal of Politics 72: 852-867. 
McFarland, Sam. G., Vladimir S. Ageyev, and Nadya Djintcharaze. 1996. "Russian Authoritarianism Two Years after Communism.” Personality and Social Psychology Bulletin 22: 210-217.

McFarland, Sam, and Melissa Mathews. 2005. "Who Cares about Human Rights?” Political Pscyhology 26: 365-385.

Meloen, J. D. 1993. “The F Scale as a Predictor of Fascism: An Overview of 40 Years of Authoritarianism Research.” In W. F. Stone, G. Lederer. And R. Christie (Eds.), Strength and Weakness: The Authoritarian Personality Today. New York: Springer Verlag. p. 4769.

Miller, Arthur H., Patricia Gurin, Gerald Gurin, and Oksana Malanchuk. 1981. “Group Consciousness and Political Participation.” American Journal of Political Science 25: 494-511.

Mirisola, Alberto, Michele Roccato, Silvia Russo, Giulia Spagna, Alessio Vieno. 2014. "Societal Threat to Safety, Compensatory Control, and Right-Wing Authoritarianism.” Political Psychology 35: 795-812.

Monroe, Carla R. 2013. “Colorizing Educational Research: African American Life and Schooling as an Exemplar.” Educational Researcher 42: 9-19.

Narby, D.J., B.L. Cutler, and G. Moran. 1993. "A Meta-Analysis of the Association between Authoritarianism and Jurors' Perceptions of Defendant Culpability.” Journal of Personality and Social Psychology 72: 1202-1216.

Peterson, Bill E., Lauren E. Duncan, and Joyce S. Pang. 2002. “Authoritarianism and Political Impoverishment: Deficits in Knowledge and Civic Disinterest.” Political Psychology 23: 97-112.

Philpot, Tasha S., and Hanes Walton, Jr. 2007. "One of Our Own: Black Female Candidates and Voters Who Support Them.” American Journal of Political Science 51: 49-62.

Popp, Elizabeth, and Thomas J. Rudolph. 2011. “A Tale of Two Ideologies: Explaining Public Support for Economic Interventions.” The Journal of Politics 73: 808-820.

Pratto, Felicia, Jim Sidanius, and Shana Levin. 2006. "Social Dominance Theory and the Dynamics of Intergroup Relations: Taking Stock and Looking Forward.” European Review of Social Psychology 17: 271-320. 
Raden, D. 1999. “Is Anti-Semitism Currently Part of an Authoritarian Attitude Syndrome?” Political Psychology 20: 323-343.

Rocha, Rene R., Caroline J. Tolbert, Daniel C. Bowen, and Christopher J. Clark. 2010. “Race and Turnout: Does Descriptive Representation in State Legislatures Increase Minority Voting? 62: 890-907.

Rubinstein, G. 2003. “Authoritarianism and its Relation to Creativity: A Comparative Study Among Students of Design, Behavioral Sciences and Law.” Personality and Individual Differences 34: 695-705.

Scherer, Nancy, and Brett Curry. 2010. “Does Descriptive Race Representation Enhance Institutional Legitimacy? The Case of the U.S. Courts.” The Journal of Politics 72: 90104.

Seltzer, Richard, and Robert C. Smith. 1985. "Race and Ideology: A Research Note Measuring Liberalism and Conservatism in Black America.” Phylon 46: 98-105.

Smith, Robert C. 1978. “The Changing Shape of Urban Black Politics: 1960-1970.” Annals of the American Academy of Political and Social Science 439: 16-28.

Stone, William F. 1980. “The Myth of the Left-Wing Authoritarianism.” Political Psychology 2: 3-19.

Stone, William F., Gerda Lederer, and Richard Christie. 1993. Strength and Weakness: The Authoritarian Personality Today. New York: Springer Verlag.

Sullivan, Jas M., and Keena N. Arbuthnot. 2009. “The Effects of Black Identity on Candidate Evaluations: An Exploratory Study.” Journal of Black Studies 40: 215-237.

Tajfel, Henri. 1981. Human Groups and Social Categories. Cambridge: Cambridge University Press.

Tajfel, H., and J.C. Turner. 1986. “The Social Identity Theory of Intergroup Behavior.” In Psychology of Intergroup Relations ( ${ }^{\text {nd }}$ Ed.) S. Worchel and W.G. Austin (Eds.) Chicago: Nelson-Hall. Pp. 7-24.

Tate, Katherine. 2003. Black Faces in the Mirror: African Americans and Their Representatives in the U.S. Congress. Princeton: Princeton University Press.

Tatum, Beverly Daniel. 1997. Why are All the Black Kids Sitting Together in the Cafeteria? And Other Conversations about Race. New York: Basic Books. 
Todosijević, Bojan, and Zsolt Enyedi. 2008. "Authoritarianism without Dominate Ideology: Political Manifestations of Authoritarian Attitudes in Hungary.” Political Psychology 29: $767=787$.

Van Hiel, Alain, and Ivan Mervielde. 2002. "Explaining Conservative Beliefs and Political Preferences: A Comparison of Social Dominance Orientation and Authoritarianism.” Journal of Applied Social Psychology 32: 965-976.

Walker, W.D., R.C. Rowe, and V.L. Quinsey. 1993. “Authoritarianism and Sexual Aggression.” Journal of Personality and Social Psychology 65: 1036-1045.

Watson, Elwood. 1998. "Guess What Came to American Politics? Contemporary Black Conservatism.” Journal of Black Studies 29: 73-92.

Wooldridge, Jeffrey M. 2013. Introductory Econometrics: A Modern Approach. $5^{\text {th }}$ Edition. Mason, OH: South-Western Cengage Learning. 
Table 1

Coding for Each Variable Included in Analysis

\begin{tabular}{|c|c|c|}
\hline Variable & Type & Description \\
\hline African-American & Dummy & $1=$ African American, $0=$ Not \\
\hline Hispanic/Latino & Dummy & 1 =Hispanic/Latino, $0=\mathrm{Not}$ \\
\hline Other Race & Dummy & $1=$ Asian $/$ Other, $0=$ Not \\
\hline Male & Dummy & 1= Male, $0=$ Woman \\
\hline Ideological & 7 Point Scale & $\begin{array}{l}\text {-3 Strong Lib., -2 Lib., } 1 \text { Weak Lib., } 0 \text { independent, } \\
1 \text { Weak Con., } 2 \text { Con., } 3 \text { Strong Con. }\end{array}$ \\
\hline Pocketbook Econ. & 5 Point Scale & $\begin{array}{l}-2=\text { Much Worse, }-1=\text { Worse, } 0=\text { Same, } 1=\text { Better, } \\
2=\text { Much Better }\end{array}$ \\
\hline Sociotropic Econ. & 5 Point Scale & $\begin{array}{l}-2=\text { Much Worse, }-1=\text { Worse, } 0=\text { Same, } 1=\text { Better, } \\
2=\text { Much Better }\end{array}$ \\
\hline Education & 7 Point Scale & $\begin{array}{l}0=\text { Some High School, 1=High School Grad, } \\
\text { 2=Some College, 3= College Grad, 4=Some Post- } \\
\text { Grad, 5=MA, 6=JD, PhD, MD, Prof. Degree }\end{array}$ \\
\hline Income & 9 Point Scale & $\begin{array}{l}0=\text { Less than } \$ 20,000,1=20-29,999,2=30-39,999 \text {, } \\
3=40-49,999,4=50-59,999,5=60-74,999,6=75- \\
99,999,7=100-149,999,8=150,000 \text { or more }\end{array}$ \\
\hline Age & 6 Point Scale & $\begin{array}{l}0=18-24,1=25-29,2=30-39,3=40-49,4=50-64, \\
5=65 \text { and over }\end{array}$ \\
\hline Political Knowledge & 9 Point Scale & $\begin{array}{l}\text { Ranges from } 0=\text { Respondent answered all of the } \\
\text { political knowledge questions wrong, to } 8= \\
\text { Respondent answered all the questions correctly. } \\
\text { Built from } 8 \text { standard ANES political knowledge } \\
\text { questions [(1) Maj. Party in Senate, (2) Maj. Party } \\
\text { in House, (3) Which party more conservative, (4) } \\
\text { Currently Unemployment Rate, (5) ID-Boehner, (6) } \\
\text { ID-Biden, (7) ID-Roberts, (8) ID- Cameron] }\end{array}$ \\
\hline Partisanship & 7 Point Scale & $\begin{array}{l}\text { Standard } 7 \text { point partisanship scale: -3 Strong Dm, } \\
\text {-2 Dem, -1 Lean Dem, } 0 \text { independent, } 1 \text { Lean Rep, } \\
2 \text { Rep, } 3 \text { Strong Rep. }\end{array}$ \\
\hline RWA scale & 240 Point Scale & $\begin{array}{l}\text { Scale ranges from } 30 \text { to } 270 \text {, based on } 30 \text { questions } \\
\text { Subtracted } 30 \text { so scale begins at } 0 \text { for regressions } \\
(0-240)\end{array}$ \\
\hline
\end{tabular}


Table 2

Right-Wing Authoritarianism Questions

1. Our country desperately needs a mighty leader who will do what has to be done to destroy the radical new ways and sinfulness that are ruining us. $\mathrm{C}$

2. Gays and lesbians are just as healthy and moral as anybody else. T

3. It is always better to trust the judgment of the proper authorities in government and religion than to listen to the noisy rabble-rousers in our society who are trying to create doubt in people's minds. C

4. Atheists and others who have rebelled against the established religions are no doubt every bit as good and virtuous as those who attend church regularly. $\mathrm{C}$

5. The only way our country can get through the crisis ahead is to get back to our traditional values, put some tough leaders in power, and silence the troublemakers spreading bad ideas. 6. There is absolutely nothing wrong with nudist camps. T

7. Our country needs free thinkers who will have the courage to defy traditional ways, even if this upsets many people. C

8. Our country will be destroyed someday if we do not smash the perversions eating away at our moral fiber and traditional beliefs. A

9. Everyone should have their own lifestyle, religious beliefs, and sexual preferences, even if it makes them different from everyone else. $\mathrm{T}$

10. The "old-fashioned ways" and "old-fashioned values" still show the best way to live. T

11. You have to admire those who challenged the law and the majority's view by protesting for women's abortion rights, for animal rights, or to abolish school prayer. C

12. What our country really needs is a strong, determined leader who will crush evil, and take us back to our true path. A

13. Some of the best people in our country are those who are challenging our government, criticizing religion, and ignoring the "normal way things are supposed to be done." $\mathrm{C}$

14. God's law about abortion, pornography, and marriage must be strictly followed before it is too late, and those who break them must be strongly punished. $\mathrm{T}$

15. It would be best for everyone if the proper authorities censored magazines so that people could not get their hands on trashy and disgusting material. A

16. There is nothing wrong with premarital sexual intercourse. $\mathrm{T}$

17. Our country will be great if we honor the ways of our forefathers, do what the authorities tell us to do, and get rid of the "rotten apples" who are ruining everything. C

18. There is no "ONE right way" to live life; everybody has to create their own way. T

19. Homosexuals and feminists should be praised for being brave enough to defy "traditional family values." C

20. This country would work a lot better if certain groups of troublemakers would just up and accept their group's traditional place in society. $\mathrm{T}$

21. There are many radical, immoral people in our country today, who are trying to ruin it for their own godless purposes, whom the authorities should put out of action. A

22. People should pay less attention to the Bible and the other old forms of religious guidance, and instead develop their own personal standards of what is moral and immoral. $\mathrm{T}$

23. What our country needs most is discipline, with everyone following our leaders in unity. $\mathrm{C}$ 24. It is better to have trashy magazines and radical pamphlets in our communities than to let the government have the power to censor them. A 
25. The facts on crime, sexual immorality, and the recent public disorders all show we have to crack down harder on deviant groups and troublemakers if we are going to save our moral standards and preserve law and order. A

26. A lot of our rules regarding modesty and sexual behavior are just customs which are not necessarily any better or holier than those which other people follow. $\mathrm{T}$

27. The situation in our country is getting so serious, the strongest methods would be justified if they eliminated the troublemakers and go us back to our true path. A

28. A "woman's place" should be wherever she wants to be. The days when women are submissive to their husbands and social conventions belong strictly to the past. $\mathrm{T}$

29. It is wonderful that young people today have greater freedom to protest against things they don't like, and to make their own "rules" to govern their behavior. C

30. Once our government leaders give us the "go ahead," it will be the duty of every patriotic citizen to help stomp out the rot that is poisoning our country from within. A

Notes: Scale adopted from Altemeyer (2004). Coding after each question to mimic Duckitt and Bizumic: $\mathrm{C}=$ Conservative, $\mathrm{A}=$ Authoritarian, $\mathrm{T}$ = Traditionalism. 
Table 3

Comparing the Demographic Distribution of the Survey Sample to AP's Exit Poll

\begin{tabular}{|c|c|c|c|}
\hline & $\begin{array}{l}\text { AP Exit } \\
\text { Poll }\end{array}$ & $\begin{array}{l}\text { Survey } \\
\text { Sample }\end{array}$ & $\begin{array}{l}\text { RWA } \\
\text { Subset }\end{array}$ \\
\hline \multicolumn{4}{|l|}{ Gender } \\
\hline Male & 47 & 48 & 49 \\
\hline Female & 53 & 52 & 51 \\
\hline \multicolumn{4}{|l|}{ Race/Ethnicity } \\
\hline White & 72 & 73 & 76 \\
\hline African-American & 13 & 15 & 12 \\
\hline Hispanic/Latino & 10 & 8 & 8 \\
\hline Asian & 3 & 3 & 3 \\
\hline Other & 2 & 1 & 1 \\
\hline \multicolumn{4}{|l|}{ Age } \\
\hline $18-24$ & 11 & 10 & 9 \\
\hline $25-29$ & 8 & 6 & 6 \\
\hline $30-39$ & 17 & 14 & 15 \\
\hline $40-49$ & 20 & 18 & 20 \\
\hline $50-64$ & 28 & 35 & 34 \\
\hline 65 and over & 16 & 17 & 17 \\
\hline \multicolumn{4}{|l|}{ Income (in thousands of \$) } \\
\hline Under 50 & 41 & 48 & 47 \\
\hline $50-99.999$ & 31 & 35 & 37 \\
\hline 100 or more & 28 & 16 & 16 \\
\hline \multicolumn{4}{|l|}{ Education } \\
\hline No High School & 3 & 2 & 3 \\
\hline High School Graduate & 21 & 19 & 16 \\
\hline Some College/Assoc.Deg. & 29 & 32 & 31 \\
\hline College Grad & 29 & 29 & 32 \\
\hline Post Graduate & 18 & 18 & 19 \\
\hline
\end{tabular}

Notes: Each column represents the percent of total for each variable. Survey Sample N = 1751; RWA Subset N = 761 
Table 4

Logit Estimates of the Likelihood of Voting for Obama in 2012

\begin{tabular}{|c|c|c|}
\hline & Model 1 & Model 2 \\
\hline \multicolumn{3}{|l|}{ Key Variables } \\
\hline RWA & $\begin{array}{l}-0.004 \\
(0.004)\end{array}$ & $\begin{array}{l}-0.005 \\
(0.004)\end{array}$ \\
\hline African-American & $\begin{array}{c}1.883^{*} \\
(0.886)\end{array}$ & $\begin{array}{l}-2.199 \\
(1.446)\end{array}$ \\
\hline RWA x African-American & & $\begin{array}{l}0.040 * * \\
(0.014)\end{array}$ \\
\hline Hispanic/Latino & $\begin{array}{c}0.918 * \\
(0.453)\end{array}$ & $\begin{array}{c}0.941 * \\
(0.464)\end{array}$ \\
\hline Other Race & $\begin{array}{l}2.396 * * * \\
(0.577)\end{array}$ & $\begin{array}{l}2.420^{* * *} \\
(0.613)\end{array}$ \\
\hline \multicolumn{3}{|l|}{ Controls } \\
\hline Male & $\begin{array}{l}-0.381 \\
(0.343)\end{array}$ & $\begin{array}{l}-0.425 \\
(0.341)\end{array}$ \\
\hline Education & $\begin{array}{c}0.051 \\
(0.122)\end{array}$ & $\begin{array}{c}0.056 \\
(0.121)\end{array}$ \\
\hline Income & $\begin{array}{l}-0.040 \\
(0.065)\end{array}$ & $\begin{array}{l}-0.042 \\
(0.065)\end{array}$ \\
\hline Age & $\begin{array}{l}0.293^{* * *} \\
(0.091)\end{array}$ & $\begin{array}{c}0.287^{* *} \\
(0.089)\end{array}$ \\
\hline Ideology & $\begin{array}{l}-0.165 \\
(0.117)\end{array}$ & $\begin{array}{l}-0.153 \\
(0.120)\end{array}$ \\
\hline Partisanship & $\begin{array}{l}-1.056 * * * \\
(0.094)\end{array}$ & $\begin{array}{l}-1.073 * * * \\
(0.097)\end{array}$ \\
\hline Political Knowledge & $\begin{array}{l}-0.293 * * * \\
(0.068)\end{array}$ & $\begin{array}{l}-0.307 * * * \\
(0.072)\end{array}$ \\
\hline Pocketbook Economy & $\begin{array}{c}0.390 \\
(0.265)\end{array}$ & $\begin{array}{c}0.409 \\
(0.276)\end{array}$ \\
\hline Sociotropic Economy & $\begin{array}{l}0.741^{* * *} \\
(0.158)\end{array}$ & $\begin{array}{l}0.788^{* * *} \\
(0.144)\end{array}$ \\
\hline Log pseudolikelihood & -164.27 & -161.68 \\
\hline Pseudo $\mathrm{R}^{2}$ & 0.68 & 0.69 \\
\hline $\mathrm{N}$ & 761 & 761 \\
\hline
\end{tabular}

Notes: $*=\mathrm{p}<.05, * *=\mathrm{p}<.01, * * *=\mathrm{p}<.001$, two-tailed. Regressions where run with cluster by state. Reestimating the models without cluster does not change the significance level of the variables. 
Figure 1: Predicted Marginal Effect of RWA on the Probabilty of Voting for Obama

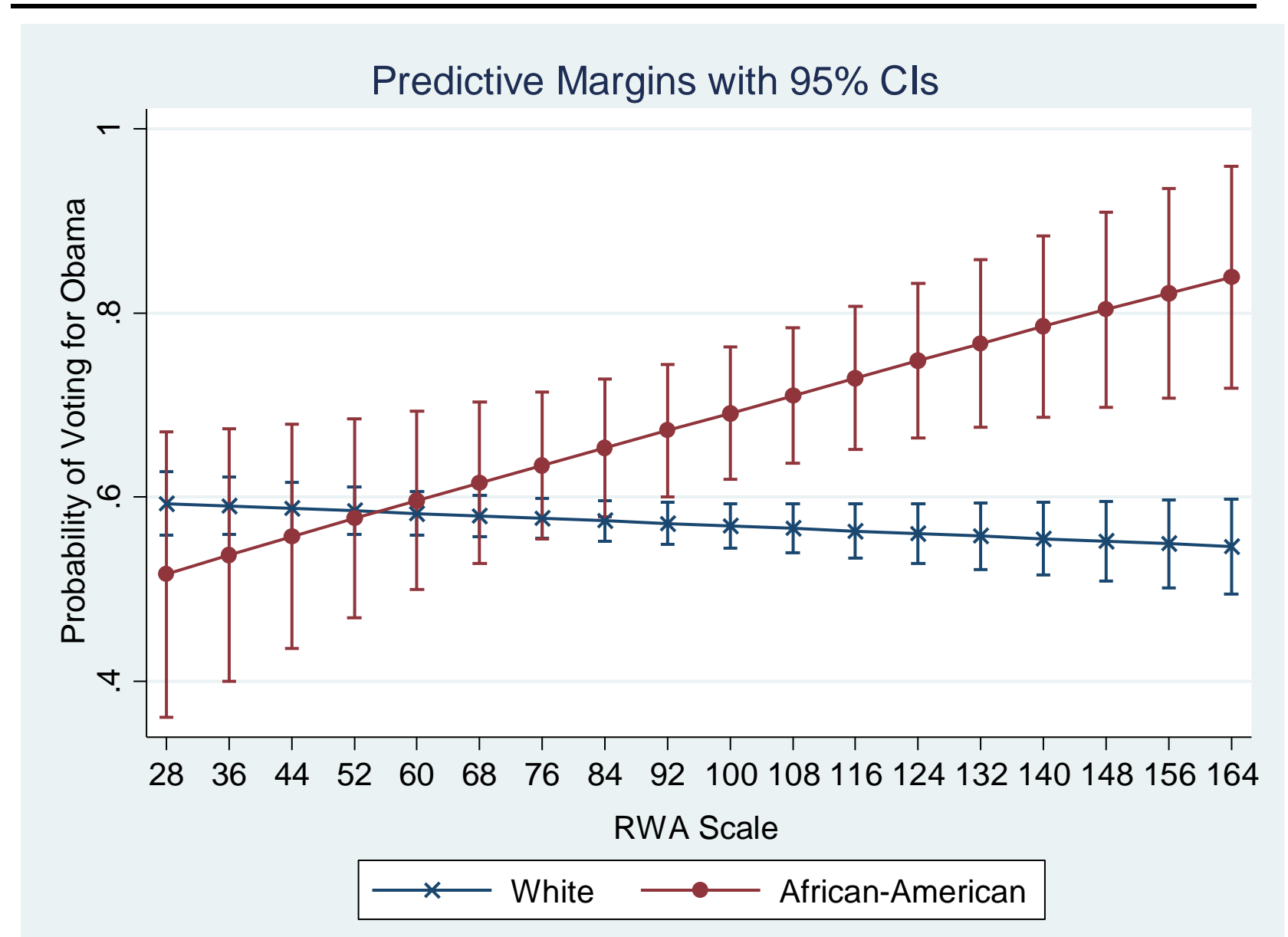


Figure 2: Predicted Marginal Effect of Duckitt and Bizumic’s Tripartite RWA Model

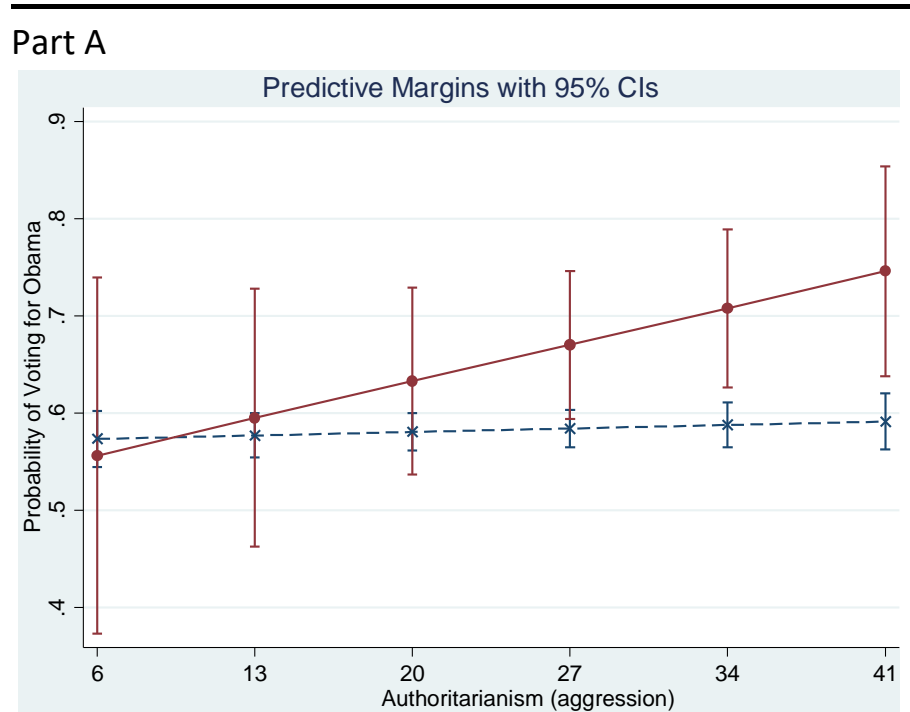

Part B

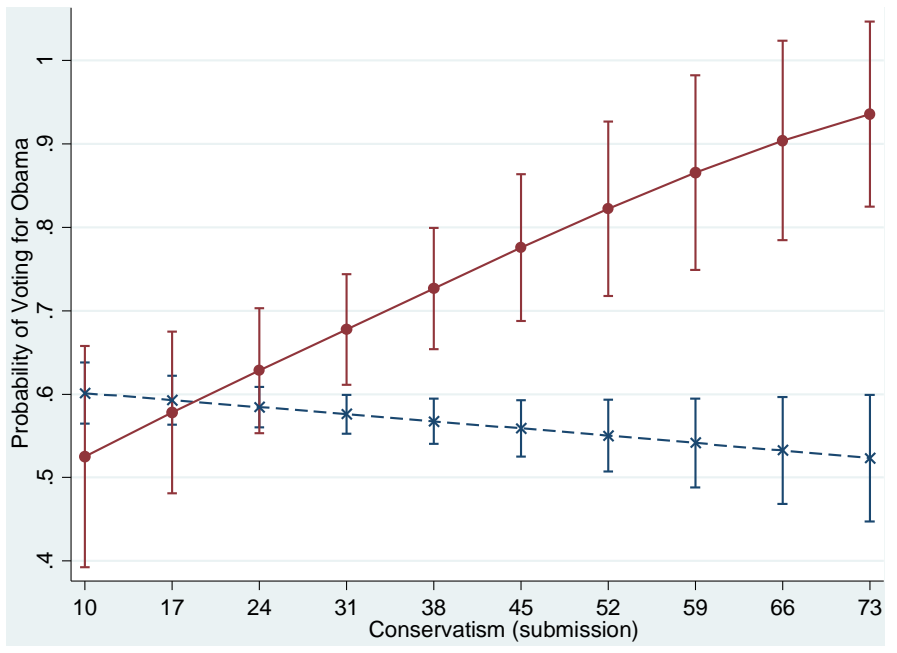

Part C

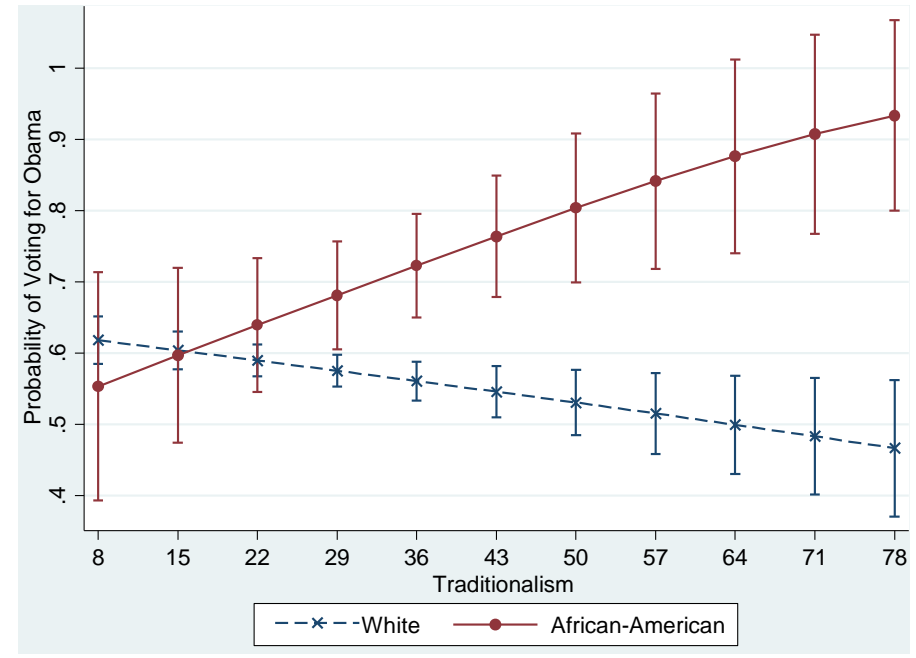

